\title{
Espelho de Narciso ou de Oxum? A poesia erótica negro-brasileira antologizada
}

Resumo: 0 artigo discute a representação da sexualidade e do erotismo na poesia de escritores negros, tendo como objeto de estudo a antologia Pretumel de chama e gozo (2015), organizada por Cuti e Akins Kintê. Qual o sentido da produção de uma escrita erótica negra, quando o ambiente político conservador e excludente exige do ativismo negro a luta pela garantia de igualdade racial e inserção do negro nas diversas instâncias sociais? O erotismo não estaria a serviço da violência e da exploração sexual do corpo negro? Como é possível pensar num erotismo que mitigue os estigmas herdados da sociedade escravocrata? A discussão aqui empreendida quer menos responder a essas indagações do que apontar percursos investigativos no erotismo de autoria negra.

Palavras-chave: erotismo, poesia negra, antologia poética, sexualidade

Abstract: This article discusses the representation of sexuality and eroticism in the poetry made by black Brazilian writers, having the anthology Pretumel de chama e gozo (2015), organized by Cuti and Akins Kintê, as its subject of study. What's the point of producing a black erotic writing when the conservative and excludent political environment demands from black activism the fight for racial equality and black people's insertion in several social instances? Isn't eroticism in the service of violence and sexual exploitation of black bodies? How is it possible to think about a different kind of eroticism, that mitigates the stigma inherited from a slave society? The discussion undertaken here wants to point to investigative routes in black authorship eroticism more than answer the questions above.

Keywords: eroticism, black poetry, poetic anthology, sexuality 


\section{Descolonizando o erótico}

Denomina-se erotismo o conjunto de representações do prazer sexual, uma linguagem poética que traduz em palavras ou imagens os afetos e os amores, as paixões e os gozos, a relação sexual e a relação do eu com o mundo. Eros é o nome que se dá tanto ao desejo sexual, quanto ao prazer propriamente dito. Tão abrangente quanto divergente, o erotismo se retroalimentou das artes na cultural ocidental, voando do mito ao conceito, do panteão das divindades ao mundo das ideias, seja na filosofia, na literatura ou na psicanálise.

Quando se discute as questões relativas ao "dispositivo da sexualidade" e seu complexo conjunto de estratégias interpelativas ao sujeito do sexo, como o faz Foucault na História da sexualidade (2015), o erotismo se coloca ao lado de conceitos como o sexismo, heterossexualidade versus homossexualidade, desejo compulsório e desejo "anormal", dominação masculina e submissão feminina, etc. São conceitos que remontam a uma episteme sempre em movimento, tensionando os discursos atuais e cobrando um revisionismo do passado.

Os sujeitos do erotismo na literatura são mesmo sujeitos do seu desejo? Suas representações poéticas dão conta da complexidade das relações afetivas em performance? Como pensar no erotismo que seja tão plural quantos os sujeitos que desejam? Essas questões têm sido respondidas nas poéticas que se desenham desde a segunda metade do século XX e que se acentuam na contemporaneidade. Poéticas que negam os discursos do binarismo de gênero, e que celebram a diversidade sexual; poéticas que demarcam o território da sexualidade como um campo secular de disputa de poder, de confronto de discursos. Poéticas que discutem o desejo e o prazer na perspectiva da intersecção com classe, raça e gênero. Poéticas que são também políticas.

Nas Américas, e especificamente no Brasil, a elaboração de um território nacional se deu a partir de uma economia escravocrata cuja dominação, branca e masculina, manifestou-se sobretudo nos domínios da sexualidade. As relações entre dominador e dominado ultrapassavam a estrutura econômica e se propagavam na constituição das relações sexuais que, diga-se, eram violentas, sexistas e racistas.

Que símbolos são incorporados ao discurso do prazer e como eles cooperam para a construção de um conceito de erotismo que signifique libertação? Oxum, a deusa iorubana do prazer e do amor, nos oferece seu espelho (abebé) para que nos miremos e vejamos que somos desejo. ${ }^{1}$ E esse desejo, por mais que queiram escravizar, tem natureza arredia e insubordinada.

\section{Do banzo ao gozo: erotização do corpo negro a serviço de quem?}

Pretumel de chama e gozo (2015) é uma antologia erótica escrita por poetas negros e organizada por Cuti e Akins Kintê, escritores ativistas do fomento às culturas negro-brasileiras. Os organizadores apresentam no lugar do posfácio um texto em forma de diálogo no qual discutem a produção do livro e a seleção dos poemas a partir da necessidade de 
o erotismo representar o desejo do corpo negro tão marcado por certos tabus, inclusive o da sensualidade. Quanto a isso, os organizadores depõem sobre a dificuldade que o negro encontra para falar sobre o erótico: "Houve poemas que tivemos de tirar porque não atendia à proposta. Deu mesmo a impressão de que nós negros temos muita dificuldade de aliar estas duas dimensões: o erótico e a identidade negra" (Cuti/Kintê 2015: 141).

Por que escrever literatura erótica, quando tantas demandas indicam que a luta por afirmação, igualdade e respeito não esgotou, pelo contrário, é urgente? Escrever literatura erótica pode ser uma atitude política dos sujeitos que precisam dizer, poética e ficcionalmente, o que desejam e como desejam. A dificuldade de inserir na pauta a sexualidade, dizem eles, se apresenta "como se a violência, a exploração, o racismo também não incidissem sobre o desejo" (ibidem).

Das cartas dos padres jesuítas aos relatos dos viajantes, a literatura de informação seiscentista desenhou um Brasil sensual, pervertido, onde os prazeres da carne punham em desassossego o mais casto cristão. Não à toa, os ensaístas modernistas, em suas tentativas de interpretação do Brasil, vão ser unânimes em reafirmar a sensualidade como um traço da formação do brasileiro. Paulo Prado chega a destacar, em Retrato do Brasil, cuja primeira edição é de 1928, um capítulo apenas para a luxúria na colônia, enquanto Gilberto Freyre apontará, em Casa-grande \& Senzala (s/d), de 1933, a relação entre senhor e escravo, que adentrava no território da sexualidade, uma relação de sadismo e masoquismo formava o caráter do adulto, eivado de perversões contra o corpo negro e indígena. O furor sexual da Casa-grande não fazia exceção: era o senhor pelas mucamas, o senhorzinho pelas amas de leite e filhas das mucamas ou pelo muleque leva-pancadas, espécie de brinquedo do menino branco. Freyre é enfático ao apontar que um sadismo da relação do senhor com o escravo que explica o fato “(...) da mulher ser tantas vezes no Brasil vítima inerme do domínio ou do abuso do homem; criatura reprimida sexual e socialmente dentro da sombra do pai ou do marido" (Freyre 1933: 86). E acrescenta ainda que esse sadismo extrapolou a esfera doméstica para penetrar no campo político que resulta no mandonismo que vigora nas relações de poder no Brasil.

Em Formação do Brasil Contemporâneo (1961), de 1942, Caio Prado Júnior discute o processo de animalização do escravo pelo colono, mera força bruta de carga, enquanto da escrava, além da força de trabalho "a passividade da fêmea na cópula" (Prado Júnior 1961: 270). Essa separação de papéis de uso dos corpos negros vai se distinguindo à medida que a escravidão se prolifera no território da colônia, a ponto de se falar de uma "onipresença do escravo" no campo e na cidade, conforme aponta Prado Júnior, ressaltando como subproduto da escravidão "as fáceis carícias da escrava para a satisfação das necessidades sexuais do colono privado de mulheres de sua raça e categoria (...)" (idem: 271).

Lélia Gonzales, uma das principais pensadoras brasileiras negras da atualidade, no artigo "Racismo e sexismo na cultura brasileira" (2019), originalmente publicado em 1984, fala do carnaval como o momento de se reencenar o mito da democracia racial, 
quando a mulher negra deixa de ser a empregada doméstica e é elevada à condição de rainha ou deusa. Violência simbólica que, segundo a autora, remonta à mucama do Brasil colônia, que engendra uma culpabilidade branca e que se converte num perigoso instrumento de desordem no plano econômico e no plano familiar, uma vez que ela se tornava o centro da disputa entre o seu senhor e outros negros (Gonzales 2019: 243-244). Gonzales retoma o pensamento de Caio Prado Júnior sobre a dupla função da escravidão no Brasil, o fator trabalho e o fator sexual, mas critica a análise empreendida por ele. Prado Júnior afirma que "[a] outra função do escravo, ou antes, da mulher escrava, de instrumento de satisfação das necessidades sexuais de seus senhores e dominadores, não tem um efeito menos elementar" (Prado Júnior 1961: 342). Gonzales contesta essa análise, afirmando que ela faz parte do que se convencionou chamar de "neurose cultural brasileira", que tem a ver, freudianamente falando, com a ocultação de um sintoma, o medo de encarar o recalque. Sobre o trecho citado, Gonzales contra-ataca: "Pelo exposto, a gente tem a impressão de branco não trepa, mas comete ato sexual e que chama tesão de necessidade. E, ainda por cima, diz que animal só tira sarro" (Gonzales 2019: 245).

Como linguagem do desejo, o erotismo é testemunho de como cada época e cultura pensam os usos do corpo e que códigos fundamentam o que pode e o que não pode na dinâmica do desejo. Entretanto, essa perspectiva do plano afetivo é atravessada por uma complexa rede de interesses alheios ao prazer e até em desacordo com ele, tais como o uso do corpo e do sexo como força de trabalho, o acordo social que regula o que é um casal ou uma família, a união religiosa ou civil, a regulação dos afetos que podem ou não ser aceitos publicamente, e daí por diante.

Ao falar das políticas sexuais para mulheres negras, nos espaços de reconfiguração do feminismo de terceira onda (década de 1970 em diante), parte do pensamento feminista afro-americano, tem reivindicado o empoderamento das mulheres pelo erotismo. Para a feminista bell hooks, " "conexões eróticas nos distanciam do isolamento e da alienação, inserindo-nos na comunidade" (hooks 2019a: 136). Já Patricia Hill Collins adverte as mulheres negras para que não abram mão das definições de sua sexualidade, porque "os sistemas de opressão tiram proveito do erótico", e assegura que "reivindicar e autodefinir esse erotismo pode se mostrar um caminho para o empoderamento das mulheres negras" (Collins 2019: 225).

Mas é o texto "Usos do erótico: o erótico como poder", da poeta e militante Audre Lorde (2019), que lança luz sobre a urgente e necessária ação de resgate do erotismo pelos negros, porque ele faz parte de uma constituição do feminino. Lorde começa seu argumento denunciando o rapto do erotismo pelo masculino, ação que se completa com a propagação de um discurso de medo do erótico, como se ele diminuísse ou desvalorizasse o sujeito que o possui: "Fomos ensinadas a suspeitar desse recurso, demonizado, maltratado e desvalorizado na cultura ocidental" (Lorde 2019: 67). E segue denunciando a deturpação do erótico em benefício dos homens e contra as mulheres. Esse programa contra o uso do erotismo pelas mulheres esconde, segundo Audre Lorde, o medo dos homens ao empoderamento feminino. 


\section{Do erotismo "pretumel"}

Um artigo escrito por Cuti $^{3}$ no qual é analisado o erotismo na poesia publicada nos Cadernos Negros (CN), ${ }^{4}$ entre os anos de 1982 e 1994, delineia a leitura dos poemas de Pretumel de chama e gozo. Nele, Cuti faz uma brevíssima apresentação da presença do erotismo na poesia brasileira para se deter nos poemas escritos por negros sobre o prazer. Mas uma questão se impõe: discurso revolucionário e erotismo combinam? Cuti faz uma crítica aos movimentos revolucionários que, assim como os conservadores, acabam também excluindo o erótico de suas pautas: “(...) O Movimento Negro segue o mesmo diapasão, desprezando a sexualidade enquanto tema, não a enxergando em sua análise do racismo, a não ser como denúncia à 'exploração sexual da mulher negra' (...)" (Cuti s/d).

A maioria dos 39 autores da antologia Pretumel tem textos publicados em um ou várias volumes dos $\mathrm{CN}$, o que, de certo modo, leva esta análise a se orientar pelo artigo de Cuti. Idealizadores e participantes de saraus, performers em saraus da periferia urbana, com vídeos espalhados nas redes sociais, atuantes nos palcos, slamers, blogueiros, ativistas do movimento negro, jornalistas, enfermeiros, mcs e músicos, etc., os poetas da antologia atuam em várias frentes sociais. Talvez, por isso mesmo, essa poesia geralmente assume um tom oralizante ou com forte inclinação para a dicção vocal, além de um tom prosaico.

Os poemas aqui estudados foram reunidos em quatro categorias: 1) os que demarcam os traços do corpo negro (cor da pele, formato dos lábios e do cabelo); 2) os que apresentam elementos dos rituais ancestrais, mas agora a serviço do erótico, como o culto aos orixás; 3) os que revisitam a história do negro no Brasil e transformam o corpo como estigma em corpo como lugar do desejo de si; 4) os que discutem temáticas urgentes das identidades de gênero e das sexualidades dissidentes.

O poema a seguir, de Sergio Ballouk, exemplifica a primeira categoria. A palavra pretume, historicamente a serviço do uso pejorativo da pele negra, aqui é reinserida e subvertida em seu sentido, uma alteração de polos de significação do negativo para o positivo. A sutileza do erótico nesse poema se mostra a partir do cheiro:

\section{PRETUME}

leve o meu pretume

em nosso costume de mordiscar a nuca

medir o corpo distraído espalmado cobiçando centímetros

palmos cavalgados

leve o meu pretume

como estou, grudado em seu íntimo

em seus colares, braceletes e brincos

meu carinho escorregadio

Chanel Pantera n० 5 


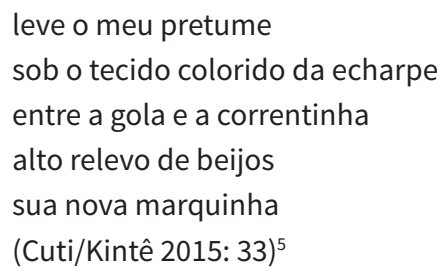

O sujeito masculino do poema fala para sua amada após o gozo. O primeiro verso de cada estrofe, uma frase imperativa repetida, aponta para as marcas que ficam nos corpos dos amantes após os momentos de prazer. Uma sinestesia entre cor e aroma ocorre no poema, quando o homem vai citando corpo, roupa, acessórios e perfume da amada, que estarão impregnados com o cheiro do amante. A citação ao perfume Chanel no 5 , referência a uma das mais caras e famosas fragrâncias francesas, aqui é associada ao cheiro do corpo preto, a pantera.

Os poemas de Pretumel constituem um mapa, uma geografia do prazer do corpo negro. Mas alguns poemas demarcam a cor da pele como um estatuto político. Nesse sentido, o discurso assume um tom engajado a serviço de uma reeducação do olhar do outro. O longo poema de Mel Adún é um exemplo desse discurso revisionista:

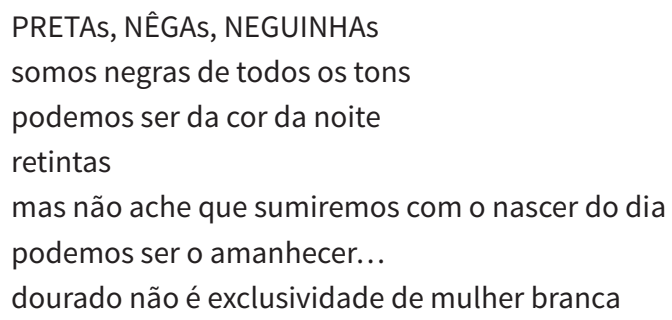

Eu e minhas irmãs temos a mesma importância as mais escuras ainda sofrem mais as mais clara ainda sofrem mais não vamos entrar no jogo das desgraças.

Somos negras de todos os tons 


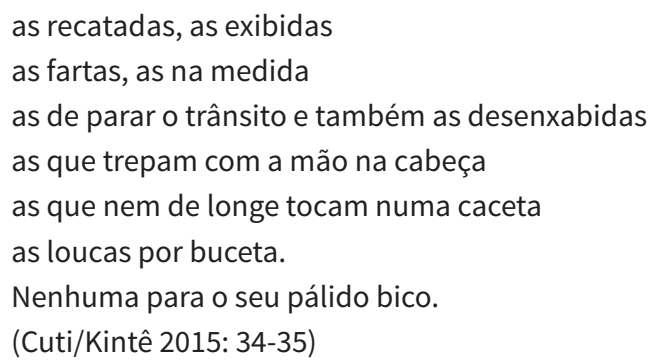

Como se vê, o poema é um manifesto à pluralidade negra, que quebra ou recusa os variados estereótipos, do biotipo ao comportamento, do sujeito desejado ao sujeito desejante. A voz da poeta, voz de mulher, convoca suas irmãs para rejeitarem o discurso fetichizante branco sobre o corpo negro, que as vê objetificadas. Tons de pele, formato dos lábios, cor dos olhos, textura capilar, todas as nuances apontadas pela poeta dão conta de uma diversidade da negritude muito além da paleta de formas e cores. O poema também tem um destinatário definido: o homem branco. É para ele que a poeta se reporta, para que ele não volte a minar a unidade preta com seu discurso de "separar para trunfar"; para que ele saiba que nenhuma das mulheres descritas ali é "para o seu pálido bico". Ou seja, a mulher preta muitas vezes foi hipersexualizada pela sociedade branca, vista como predisposta ao prazer do outro e anulada como sujeito desejante. Daí a urgência de poemas como de mel Adún, que oferece ao leitor a possibilidade de, pela poesia, aprofundar sua consciência sobre o corpo negro, conforme sugere Cuti: "O aprofundamento de uma consciência negra no Brasil pressupõe uma concepção do corpo distanciada da divisão do ser. A poesia negra contemporânea elabora, dentre outras coisas, esta possibilidade (...)" (Cuti s/d).

O poema de Adún também é marcado por um subtexto, quando o título parece estabelecer um diálogo com a letra da canção “Preta, pretinha”, escrita por Luís Galvão e musicada por Morais Moreira, que faz parte do disco Chorare, lançada pelos Novos Baianos em 1972. Uma das faixas de maior sucesso do disco, a letra da canção apresenta os versos "assim vou the chamar / assim você vai ser / preta, preta, pretinha", enquanto o título do poema de Adún parece reescrever o verso da canção para suscitar o debate sobre a pluralidade da pele negra. Enquanto os radicais das palavras estão em caixa alta, a desinência de número vem em caixa baixa para demarcar o coletivo versus singular. Não se trata de anular o uso de "preta", "nêga" ou "neguinha" como qualificativos carinhosos, mas de demarcar neles a natureza diversificada do olhar sobre o negro.

Como exemplo da segunda categoria, o poema de Zannah Lopes exige do leitor um mergulho na rica e complexa mitologia iorubana do culto aos orixás. Nós, periféricos ocidentais, pagamos tributo aos deuses do panteão greco-latino (Eros, Afrodite, Priapo...) e esquecemos ou desconhecemos que os deuses dos cultos africanos também flertam, transam, têm "homéricas" fodas com deuses e com humanos, enfim, estão em 
comunhão erótica com a natureza. Quando o negro fala de erotismo, certamente vai encontrar no complexo cultural afro-diaspórico os conceitos, mitemas e referenciais simbólicos para ajudá-lo a elaborar seu pensamento. ${ }^{6}$ Vejamos o poema:

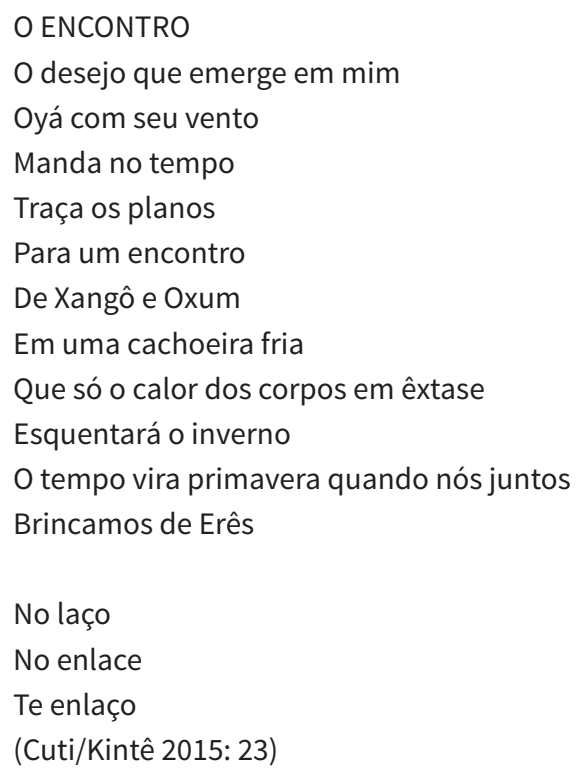

Mais do que demonstrar a afrodescendência, esses referenciais simbólicos oferecem ao leitor a possibilidade de reconfigurar o erotismo a partir de outras perspectivas que não as da cultura greco-latina tão apreciada pelas culturas das ex-colônias. Uma alfabetização às narrativas dos orixás é exigida para se compreender o poema, uma vez que a poeta estabelece uma convergência entre o desejo que nasce em si e a atuação dos Orixás. O desejo é como o vento de lansã ou o encontro de Oxum, o orixá do fogo e dos raios, com sua amante, a bela Oxum, orixá da sensualidade e do empoderamento feminino. Assim, o encontro entre a poeta e seu amado não é somente comparado ao encontro de Xangô com Oxum, mas é por esses deuses celebrado. É lugar-comum usar o termo "brincar" para o ato sexual. Mas no poema, brincar é potencializado pelo uso da palavra Erês, ${ }^{7}$ que representa justamente a consciência de fusão entre o humano e seu orixá, o momento em que as duas consciências se afirmam. Nesse sentido, a brincadeira de Erês dos amantes é a expressão mais original da tradução à cultura afro-brasileira do poder do erótico. Como se vê, a simplicidade da letra do poema dá lugar a uma complexa rede de referências subjacentes à mitologia africana.

Nessa mesma linha, o poema de Zula Gibi está assentado nas matrizes africanas, no culto a Oxum, orixá da beleza e das águas doces: 


\author{
OXUM \\ No espelho d'água \\ contemplava-se \\ contornos arredondados \\ Amou-se \\ Água de cachoeira \\ límpida e misteriosa \\ desaguando intensa \\ redemoinhos no leito do rio \\ Molhava-se \\ na rubra gruta secreta \\ envolveu-se em profundidades \\ provou sabores \\ Entre ais e ais em si mesma \\ deleitou-se \\ Mandou Narciso às favas \\ Ninguém morre se amando \\ (Cuti/Kintê 2015: 68)
}

Quem é de Oxum não precisa de Xangô para sentir prazer. A sutil descrição de uma masturbação feminina vai agenciando nossos sentidos à medida que o texto avança: é o olhar que motiva o erótico na contemplação do próprio corpo no espelho d'água, é o atrito da água corrente no corpo desejante, são os dedos penetrando a "rubra gruta secreta" e os gemidos que esse prazer evoca. Ora, se Oxum é arquétipo do autoconhecimento feminino, o poema de Zulah Gibi só pode valorizar esse saber ancestral. É como se o poema afirmasse que nenhuma mulher pode ser amada se primeiro não se amar, e esse amor começa sobretudo pela experimentação do prazer solitário. Os dois versos finais constituem o confronto entre duas culturas diferentes a respeito do autoprazer: Narciso, representante da mitologia hegemônica, é confrontado com Oxum, representante da mitologia diaspórica. Ambos são apaixonados pela sua própria beleza, mas, enquanto Narciso morre afogado na contemplação de sua face, Oxum contempla e goza sua beleza como afirmação e celebração da vida.

$\mathrm{Na}$ análise dos poemas dos $\mathrm{CN}$, Cuti já falava sobre como as poetas negras investiam na proximidade dos ritos afros com a poesia e tendiam a sempre pensar a sexualidade em sua totalidade, ou seja, o corpo e o prazer negros passam a ser uma metonímia do 
corpo social. Nesse sentido, Cuti enfatiza que “(...) a cultura e a comunidade afro-brasileira, sendo essencialmente matriarcal, impõe sua resistência ao machismo (...). O mensageiro dos Orixás não é privilégio dos homens" (Cuti s/d).

Na terceira categoria temática, a geografia do corpo mapeia cartografias, fazendo com que a memória do corpo individual exorcize a memória do corpo coletivo marcada por uma história na qual o sofrimento se dava sobretudo pela negação do prazer de uns em favor da satisfação de outros. Essa cartografia é referendada, às vezes, por um único vocábulo, caso do poema "Território", de Lande Onawale, cujo termo "desejos aquilombados" delimita a leitura, mas só aparece na última estrofe. Se o poema não constasse de uma antologia de poesia negra, ou se não conhecêssemos o autor, teríamos a chave para a compreensão de que se trata da identidade negra aí representada somente ao final do texto:

\author{
TERRITÓRIO \\ Onde quer que esse beijo pouse \\ glande, falange, fundo do ouvido \\ há de estremecer o corpo \\ assanhar o sangue \\ revoar gemidos \\ onde quer que essa língua deslize \\ ânus, virilhas, axilas \\ há de corromper certezas \\ deixar as veias tesas \\ surpresas
}

onde esse dedo roce

provoque, evoque...

algo em mim responderá ao chamado...

\title{
desejos aquilombados
}

libertam o território do meu corpo

\section{(Cuti/Kintê 2015: 17; grifo meu)}

Como pode um poema erótico suscitar uma história coletiva? Uma poesia assim não estaria na contramão do erotismo? Não é o que esses poemas provam. Em "Sentimentos condensados", o sujeito lírico do poeta Cizinho Afreeka deseja liberar os sentimentos presos ao ver o corpo da outra. Mais uma vez, o que sugere no poema a identidade negra não é a existência de palavras que representem a melanina e as formas do corpo negro; é justamente a referência a situações da história do negro no Brasil colonial e imperial, na sequência de ausências necessárias ao prazer que a preposição "sem" reúne: 


\author{
SENTIMENTOS CONDENSADOS \\ Com tanto apetite \\ Se te vejo na minha frente... \\ Despedaço-te \\ Contente, contando \\ Cada parte tua, nua \\ Nuanças de prazer em cada membro \\ Nos gestos e toques \\ Retoques \\ Modelam sentimentos condensados \\ Intumescidos
}

\title{
Aprendo a expressá-los sem amarras
}

Sem vergonha, sem corrente

Sem chicotes, sem senhores

Sem senhoras, sem vergonha

Sem senzala, sem sistemas

Sem esquema, sem delírio

Sem martírio, sem ódio

Sem medo, sem!

Mas com você

Como se fosse o último diapasão

Ou o primeiro

Saboreio-te, meu alimento melodia.

(Cuti/Kintê 2015: 50; grifo meu)

Os desejos do eu poético estão aprisionados, retidos, "intumescidos", e só esperam o outro para se desvencilhar das amarras. A repressão dos desejos apontada no poema de Cizinho é justificada na terceira estrofe como uma herança histórica, na relação dos senhores com seus escravos quando, além de peças de trabalho, muitas vezes se tornavam peças de um jogo sádico sexual dos brancos.

De fato, falar do erotismo e, sobretudo, escrever literatura erótica, menos do que tabu é, muitas vezes, um inconveniente aos escritores negros, fruto de uma dupla autocensura: a primeira é elaborada pela história da escravidão, quando se esperava tudo do corpo negro, menos que sentisse prazer; a segunda desqualifica o uso do erótico, anulando-o da produção poética porque se entende que a urgência é escrever literatura engajada, comprometida com as políticas de igualdade racial. É preciso não cair no jogo sujo de uma tradição masculina e heterocentrada que usurpou o uso do 
erótico, conforme apontou Audre Lorde (2019).

Por fim, antes de analisar os poemas que se situam na quarta categoria, façamos um breve histórico. A terceira onda do feminismo promoveu uma série de rupturas no movimento, sem, no entanto, enfraquecê-lo: além de questionar o conceito universalizante da categoria mulher, abalou a estrutura da heterossexualidade hegemônica negando esse contrato heteronormativo. Foram mulheres feministas lésbicas e negras que contribuíram para a urgência de um olhar plural sobre o feminismo, berço daquilo que seria englobado como estudos queer. As contribuições e herança dessa luta não são poucas: a ideia de que masculino e feminino são construções culturais performativas, a contestação das identidades de gênero binário, a recusa ao contrato heterossexual pelos gays e lésbicas, a designação das performatividades homoafetivas, a imposição da revisão da masculinidade e virilidade, são apenas algumas das novas categorizações dos dispositivos da sexualidade que viriam tensionar os discursos acostumados.

Justamente pela importante contribuição das ativistas negras e lésbicas aos estudos da sexualidade Pretumel carece de uma maior representatividade do homoafeto negro. A heteronormatividade compulsória domina a seleção, apesar de haver poetas trans, gays e lésbicas aí presentes. Mas uma coisa é o autor afirmar sua identidade sexual e de gênero, a outra é marcar seu texto com uma carga semântica que conduza o leitor nas veredas da homoafetividade. Se o erotismo do corpo negro, para ser representado textualmente, lança mão de texturas vocabulares que reúnem a história coletiva, as referências da cultura periférica contemporânea e as cores e formas fenotípicas dos corpos desejantes, o que esperar de um texto de autoria negra de viés homoerótico? Como essa representação de afetos se desenha que identifique aí marcas singulares? Já se disse que o complexo cultural afro-diaspórico é um baú onde os teóricos e artistas negros têm ido procurar aproximações e entendimentos de seu ser social, político e estético.

O poema de Sueide Kintê aborda um duplo tema, caro aos movimentos que lutam contra o sexismo e a violência sexual. A voz do poema é de uma mulher, na cama com seu parceiro, ambos negros. A cada estrofe, em vez de uma descrição de prazer, vamos sendo partícipes da insatisfação da mulher. Onde estaria, portanto, o erotismo nesse poema?

\footnotetext{
VIÉS

E dessa vez o corpo entalou o gozo

não decifrou meu feminino plural

Escura tez, falo farto, fogoso

ele copula feito canibal

Ele não lê minhas partituras

nada no seco, cospe, mete

bota, tira, promove rupturas

saliva, mas, não molha nem derrete
} 
Bate seco como concreto

do meio até a anca

Dispenso aquele membro ereto

eu quero é vulcro pra ser franca

Naquele preto peito

fujo e penso só nela

lembro da língua lambendo direito

e do marcante perfume de canela

A mente me transporta no ritmo

do nosso batimento perfeito

a cadência que enquadra o íntimo

e $o$ ar que fica rarefeito

Desse jeito me encaixo

dispensando o varão

gozo sozinha e estou por cima

embora ele me tenha debaixo

A cabecinha em mim

e minha cabeça nela

gozo num desejo sem fim

a espera do abraço dela

(Cuti/Kintê 2015: 119)

Se não há uma violência explícita no texto, tudo nele é indício de insatisfação. Se não há prazer para um, por que continuar com a entrega? E qual o motivo desse não prazer? "Ele copula feito canibal". Somente na quinta estrofe sabemos que, enquanto o amante transa sem decifrar ou ler a partitura da outra, ela deseja outro corpo, e não de um homem, mas de uma mulher. O leitor é transportado junto com o eu lírico à imagem do prazer lésbico. O gozo vem, mas por causa das imagens de prazer com a outra. Afinal, estamos diante de um desejo bissexual ou homossexual? O que seria a decifração do feminino plural apontada na primeira estrofe? O poema instiga desde o título. A palavra viés, polissêmica, aqui sugere o desejo escondido do sujeito lírico, como o tecido dobrado e costurado para dar acabamento à roupa, ou ao modo oblíquo e tortuoso desse desejo homossexual? Qual o viés do desejo de quem, na cama com um está gozando com a imagem da outra?

Já o poema de Jennyfer Nascimento, ao tematizar o desejo e o prazer na perspectiva do negro, procura explicitar diversos campos semânticos. As referências à cor da 
pele, ao formato do corpo, à herança afro-diaspórica e aos ritos ancestrais elaboram o discurso do prazer homoafetivo lésbico:

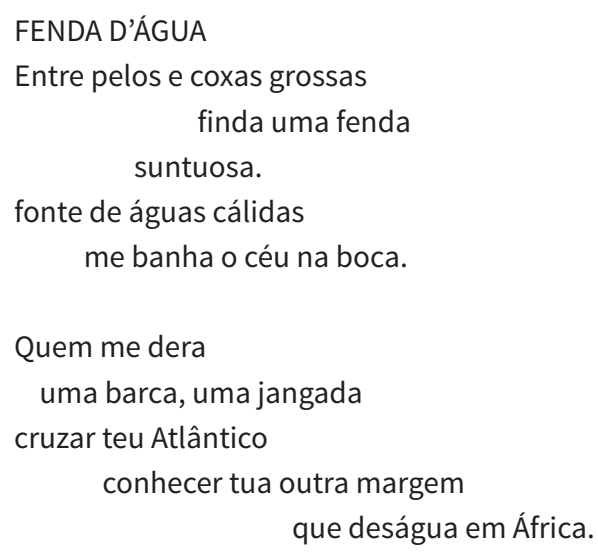

Mulher, mulher

minha lansã se encontrou com tua Oxum

trocaram carinhos e oferendas.

Respirei fundo, gemi.

Os teus olhos saltaram.

Nasceu o encontro das águas.

Odoiá, lemanjá.

(Cuti/Kintê 2015: 127)

Não bastasse a conjugação de referências interseccionadas, a mancha gráfica é também um texto a sugerir um contexto erótico. Os versos das cinco estrofes serpenteiam o papel, na dança dos corpos que se amam. Ou seja, fundo e forma performam o prazer lésbico. Mais uma vez, os orixás frequentam o poema não somente para assegurar a herança ancestral, mas para celebrar o amor lésbico. Orixás dos prazeres das águas doces, Oxum e lansã são associadas aos amores bi e homossexuais. A sedução de Oxum a lansã é uma das narrativas reunidas por Reginaldo Prandi em Mitologia dos Orixás (2001: 325) a partir da pesquisa sobre politeísmo afro-brasileiro desenvolvida pela pesquisadora argentina Rita Laura Segato. ${ }^{8}$ Trabalhos assim vão ao encontro do espelho de Oxum como metáfora, ou seja, os textos de autoria negra, quer literários, quer críticos, são o abebé onde podem os leitores se mirar. ${ }^{9}$ 


\section{Conclusão}

Seguramente, a poesia é o suporte por meio do qual o erotismo tem sido mais frequentemente veiculado. Século após século, estética após estética, o erótico é um tema tão recorrente que podemos afirmar que se trata de um gênero poético. Quando se lê um texto erótico, menos se revela os corpos dos sujeitos que desejam e saciam os seus apetites sexuais do que se descortina uma verdade: a sexualidade e seus entornos como uma construção cultural.

Pensar a literatura na contemporaneidade pressupõe repensar a teoria e a crítica constantemente. Os discursos políticos das minorias não aceitam que se pense a literatura destituída de uma política de representação ou de uma consciência de si. E é nesse sentido que se deve voltar para a literatura erótica escrita por autores negros. Diante dos estigmas da escravidão, pode o negro falar de desejo? O que revelará seu eros e seu ethos?

O conceito de erotismo a ser performado na obra, de diferentes modos e formas, é apresentado não somente como atração física, energia que move, mas, sobretudo, como aquele que não apenas sofre as consequências de um controle social, mas também se vê no centro de uma disputa de poder. Para os organizadores da obra, o controle "deriva para o exagero em nome da luta pelo poder ou pela permanência nele, luta travada entre indivíduos e grupos que, egoisticamente, objetivam monopolizar o prazer em todos os sentidos" (Cuti/Kintê 2015: 7-8).

É preciso que os sujeitos minoritários reivindiquem para si o uso do erótico como pulsão de vida, afinal, é por esse aspecto que se compreende a dimensão política do erótico. É preciso, portanto, profanar ${ }^{10}$ o uso do erotismo pelo sistema masculino branco e hétero. E isso significa reaver o seu uso, redescobrir, sobretudo pelas mulheres negras, esses usos como potência para a autodescoberta e para a libertação dos sistemas de opressão a que tanto os negros foram expostos. Há moralismo em demasia tentando ditar o ritmo dos corpos, e é preciso ser vigilante para não cair nas artimanhas do conservadorismo. Erotismo pode, sim, ser pensado como uma poética política.

\section{NOTAS}

\footnotetext{
* Claudicélio Rodrigues da Silva é professor de literatura brasileira na Universidade Federal do Ceará e membro do PPGLetras-UFC. Coordena o "Grupo de Estudos da Língua de Eros” (GELE), que tem se debruçado sobre os eixos do erotismo e da pornografia na poesia e na prosa contemporâneas. Seu mais recente projeto de pesquisa investiga o prazer e o desejo nas antologias literárias de ou sobre sujeitos dissidentes (mulheres, negros e LGBTQ).
} 
${ }^{1}$ Essa associação eu tomo de Conceição Evaristo que, em suas palestras, tem dito que, ao invés de se mirar nas águas de Narciso, o brasileiro deveria, por conta de sua ancestralidade afro, se mirar no espelho de Oxum.

${ }^{2}$ bell hooks grafa seu nome sempre em minúscula como forma de problematizar os padrões acadêmicos.

${ }^{3} \mathrm{O}$ texto não tem referência a data de escrita ou publicação. Compõe a sessão de ensaios do site Quilombhoje. Portanto, ao citá-lo, optei por utilizar o nome do autor seguido de s/d.

${ }^{4}$ Os CN (doravante será utilizada essa abreviatura) foram uma experiência revolucionária da luta negra brasileira, uma vez que os escritores negros procuraram nessas antologias, publicadas com certa periodicidade, elaborar as bases de uma literatura negro-brasileira.

${ }^{5}$ Para facilitar a referenciação, os poetas serão identificados no corpo do texto, enquanto no sistema autor/ data virá os nomes dos organizadores da antologia.

${ }^{6}$ É o caso, por exemplo, da aproximação dos estudos da sexualidade lésbica com a orixá Oxum.

${ }^{7}$ Embora no Brasil se costume traduzir Erê por criança, na língua iorubana ERÉ ou IRÉ é substantivo para jogo e brincadeira. Cf. Beniste, 2019.

${ }^{8} \mathrm{Não}$ à toa, as narrativas dessas mitologias têm migrado para o campo da investigação acadêmica. É caso do estudo de doutorado de Tatiana Nascimento dos Santos, que traduziu para o português textos críticos de feministas afro-americanas lésbicas e cujo trabalho denominou "Letramento e tradução no espelho de Oxum: teoria lésbica negra em auto/re/conhecimentos" (2014).

${ }^{9}$ É o que tem costumado afirmar Conceição Evaristo em suas conferências, e é também o que sustenta o trabalho de tradução de intelectuais negras na tese de Tatiana Nascimento dos Santos.

${ }^{10}$ Ver conceito de profanação em Agamben 2007.

\section{BIBLIOGRAFIA}

Agamben, Giorgio (2007), Profanações. Tradução Selvino José Assmann. São Paulo: Boitempo.

Beniste, José (2019), Dicionário Yorubá-português. Rio de Janeiro: Bertrand Brasil.

Collins, Patricia Hill (2019), Pensamento feminista negro: conhecimento, consciência e a polítia do empoderamento. Tradução de Jamile Pinheiro Dias. São Paulo: Boitempo.

Cuti (s/d), "Poesia Erótica nos Cadernos Negros". <https://www.quilombhoje.com.br/ ensaio/cuti/TextocriticoErotismoCuti.htm> (visitado em 20 de junho de 2020).

Cuti/ Akins Kintê (org.) (2015), Pretumel de chama e gozo: antologia da poesia negrobrasileira erótica. São Paulo: Ciclo contínuo.

Foucault, Michel (2015), História da sexualidade: a vontade de saber. Tradução Maria Thereza da Costa Albuquerque e J. A. Guilhon Albuquerque. Rio de Janeiro/São Paulo: Paz \& Terra. 
Freyre, Gilberto (s/d), Casa-grande \& senzala. São Paulo: Círculo do livro [1933].

Gonzales, Lélia (2019), "Racismo e sexismo na cultura brasileira" [1980], Pensamento feminista brasileiro: formação e contexto. Ed. Heloísa Buarque de Hollanda. Rio de Janeiro: Bazar do tempo, pp. 237-258.

hooks, bell (2019a), O feminismo é para todo mundo: políticas arrebatadoras. Tradução de Ana Luiza Libânio. Rio de Janeiro: Rosa dos Tempos.

-- (2019b), Olhares negros: raça e representação. Tradução de Stephanie Borges. São Paulo: Elefante.

Lorde, Aurde (2019), Irmã outsider. Tradução Stephanie Borges. Belo Horizonte: Autêntica. Prado Júnior, Caio (1961), Formação do Brasil contemporâneo. São Paulo: Brasiliense [1942].

Prado, Paulo (2012), Retrato do Brasil: ensaio sobre a tristeza brasileira. São Paulo: Companhia das Letras [1928].

Santos, Tatiana Nascimento dos (2014), "Letramento e tradução no espelho de Oxum: teoria lésbica negra em auto/re/conhecimentos"- Florianópolis, SC. Tese (doutorado) - Universidade Federal de Santa Catarina. Programa de Pós-Graduação em Estudos da Tradução.

Segato, Rita Laura (1995), Santos e daimones: o politeísmo afro-brasileiro e a tradição arquetipal. Brasília: Editora da Universidade de Brasília. 